\title{
Ichthyofauna of two streams in the high basin of the Samborombón River, Buenos Aires province, Argentina.
}

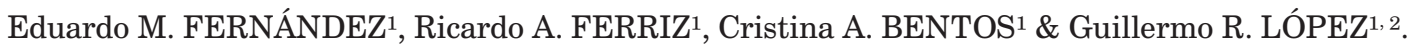 \\ ${ }^{1}$ Museo Argentino de Ciencias Naturales "Bernardino Rivadavia”. Av. A. Gallardo 470, 1405 Buenos Aires, Rep. \\ Argentina.maradentro@fibertel.com.ar; rferriz@macn.gov.ar; cbentos@macn.gov.ar. ${ }^{2}$ Facultad de Veterinaria \\ (UBA), Área de Medicina, Producción y Tecnología de Fauna Acuática y Terrestre. glópezfcruba@yahoo.com.ar
}

\begin{abstract}
The ichthyofauna of the Manantiales (3502'34"S; 58 19 '37”W) and El Portugués (3504'16"S; $58^{\circ} 26^{\prime} 09^{\prime \prime}$ ) streams, both of them pertaining to the high basin of the Samborombón River, in the Province of Buenos Aires, Argentina, was studied. Abundance, specific richness, diversity and temporary distribution were considered throughout an annual cycle. The specific diversity between both streams was compared and the physical and chemical parameters of the environment analizad. In total 8595 specimens were captured, pertaining to 20 species, 11 families and 5 orders. The order Characiformes was the most widely represented with 10 species and a relative abundance of $50 \%$, followed by the order Siluriformes with 6 species and a relative abundance of $30 \%$. The specific richness in the Manantiales was of 20 species, the annual diversity index was 1.42 and the uniformity index was 0.58 . The specific richness in El Portugués was of 17 species, the annual diversity index was 1.51 and the uniformity index was 0.64 . Differences in the composition of dominant species were observed. The diversity values are similar to that recorded in Pampasia and southern Brazil streams.
\end{abstract}

Key words: fishes, biodiversity, Manantiales and El Portugués streams, Buenos Aires, Argentina.

Resumen: Ictiofauna de dos arroyos en la alta cuenca del río Samborombón, provincia de Buenos Aires, Argentina. Se estudió la ictiofauna de los arroyos Manantiales (3502'34''S; 58¹9'37''W) y El Portugués (3504'16'S; 58²6’09'W), pertenecientes a la alta cuenca del río Samborombón, provincia de Buenos Aires, Argentina. Se brindó especial énfasis en la abundancia, riqueza específica, diversidad y distribución temporal a lo largo de un ciclo anual. Se capturaron 8.595 ejemplares, pertenecientes a 20 especies, 11 familias y 5 órdenes. El orden Characiformes fue el más representado con un total de 9 especies y una abundancia relativa de 72,5\%, seguido de los Siluriformes con 6 especies y una abundancia relativa de 16,9\%. La riqueza específica en Manantiales fue de 20 especies, el índice de diversidad anual, 1,42 y el índice de uniformidad, 0,58. La riqueza específica en El Portugués fue de 17 especies, el índice de diversidad anual, 1,51 y el índice de uniformidad, 0,64. Se observaron diferencias en la composición específica de las especies dominantes. Los valores de diversidad son semejantes a los registrados en arroyos de la Pampasia y del sur de Brasil.

Palabras clave: peces, biodiversidad, Arroyos Manatiales y El Portugués, Buenos Aires, Argentina.

\section{INTRODUCTION}

The ichthyofauna of South American continental waters, which is the richest and most diversified on the planet, is still mostly unknown (Reis et al., 2003). Distribution and specific composition are the most important factors in ichthylogical communities studies (Meffe \& Berra, 1988; Matthews, 1998). In the Neotropical region, alternation of dry and flood seasons is mostly responsible for changes in the structure of freshwater fish fauna (Lowe-McConnell, 1987). However, in temperate seasonality rivers in the Pampasia, a fairly constant specific species composition and a high persistence of species are observed (Menni, 2004). Furthermore, fish in fluvial systems tend to present changes in their patterns of distribution and habitat use, because of temporary varia- tions which are linked to reproduction and search for food (Gorman, 1988; Wootton, 1990).

Rivers and streams in the province of Buenos Aires have been scarcely studied in comparison with lake environments (Menni, 2004). Even though the number of works on the ichthyofauna in lotic environments of this province increase over the past few years (López, 1990; Almirón et al., 1992; Almirón et al., 2000; López et al., 2001; Remes Lenicov et al., 2005, Liotta, 2006), the knowledge of the distribution patterns in these environments is still hardly known. Querol et al. (1997) stress the importance which low order watercourses present in lotic systems, because most of the species complete in these places their reproductive cycles and play an ecological role as transferrers of energy.

Ichthyographically, the studied streams are in the Pampasic Domain of the Brasilian Subregion 


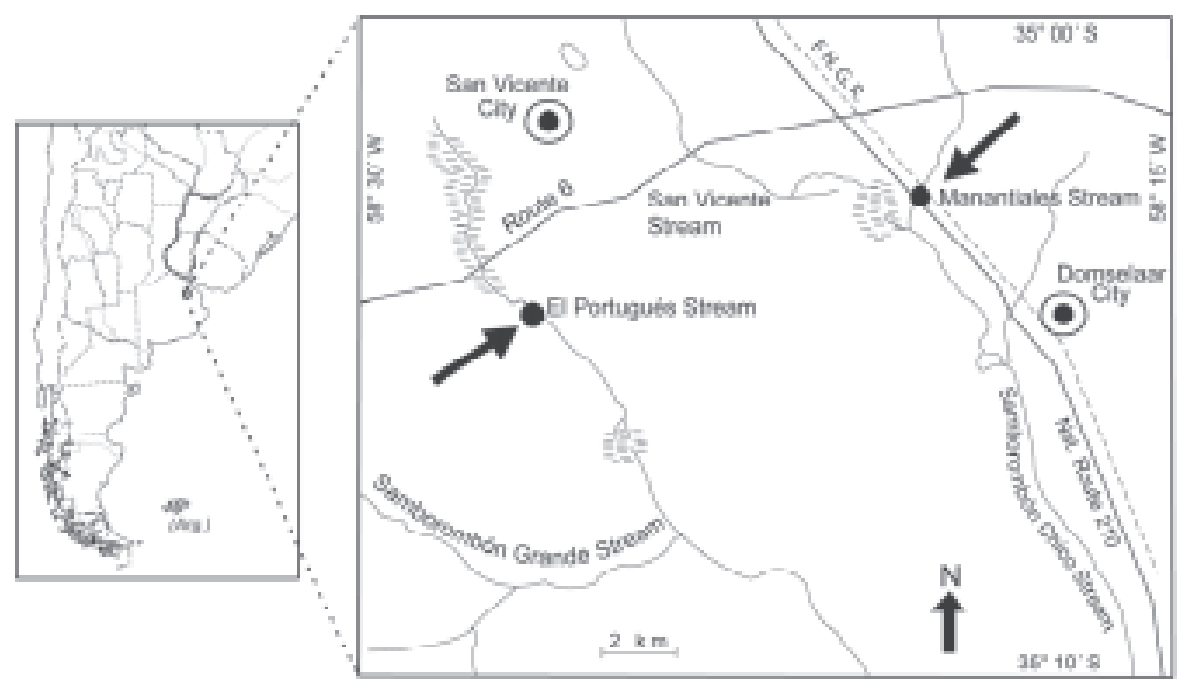

Fig. 1. Location of sampling stations in the Manantiales and El Portugués streams, Buenos Aires province, Argentine.

(Ringuelet, 1961 and 1975). López et al. (2002) locate the Samborombón River basin in the southern boundary of the Subtropical Potamic Axis Ecoregion. The Samborombón River basin has a total area of $6000 \mathrm{~km}^{2}$ (Liotta, 2006).

In the present work we studied the ichthyofauna, composition and dynamics of two streams pertaining to the high basin of the Samborombón River, emphasizing the specific composition, permanence over time, abundance and temporary distribution of the fish community.

\section{Study area}

The present work was carried out in the

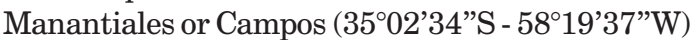
and El Portugués $\left(35^{\circ} 04^{\prime} 16^{\prime \prime} \mathrm{S}-58^{\circ} 26^{\prime} 09^{\prime \prime} \mathrm{W}\right)$ streams, both of them pertaining to the high basin of the Samborombón River, in the district of San Vicente, Buenos Aires province (Fig. 1). The Manantiales stream is a second order body of water, tributary to the Samborombón Chico River. Its water has low turbidity; a velocity ranging from medium to high in rising water but pools are formed in the still water season. The floating vegetation is characterized predominantly by water primrose, Ludwigia pepoloide; water poppy, Hydrocleys nymphoides and water fern, Azolla filiculoide. In the shallow waters next to the riverbank, bacopa turf, Bacopa monnieri prevails. The bottom of the stream consists of slime and tufa.

El Portugués stream is a first order water body tributary to the Samborombón Grande River. Its water is brown and not very clear because of the great amount of diluted humic acid. The water velocity is low in winter and the stream remained stagnant during summer, when pools were formed. The bottom is predominantly slime. Cattle rising have an important impact on this area. The submerged vegetation is characterized by the predominance of Myriophyllum aquaticum and Bacopa monnieri. The dominant floating vegetation in the sampling stations is represented by water primrose, Ludwigia pepoloide; water poppy, Hydrocleys nymphoides; water fern, Azolla filiculoide, and several species of duckweeds pertaining to the genera Lemna and Spirodella. Among the predominant marsh plants are the California bulrush, Schoenoplectus californicus, and the giant arrowhead, Sagitaria montevidensis. The shallow marshy banks are covered with Bacopa monnieri turf. In both streams land vegetation on the banks of the sampling areas consists of pastures of pulses with no trees or bushes.

\section{MATERIALS AND METHODS}

Two sampling stations were established, one in the Manantiales stream $1.5 \mathrm{~km}$ from the confluence of the Manantiales with the San Vicente river, and another in El Portugués stream $6 \mathrm{~km}$ from its source (Fig. 1). Monthly samplings were carried out in both of them from May 2004 to April 2005.

A trawl mesh of $5 \mathrm{~mm}$ between knots, 10 metres long and 1.8 metres high and a trawl mesh with a metallic frame of $50 \mathrm{~cm}$ x $30 \mathrm{~cm}$, of $2 \mathrm{~mm}$ 
Table 1. Physical and chemical characteristics of the Manantiales and El Portugués streams, from 10 samples. The mean of each variable is shown between brackets.

\begin{tabular}{lcc}
\hline & Manantiales & El Portugués \\
\hline Depth $(\mathrm{cm})$ & $0.35-0.88(0.65)$ & $0.17-0.55(0.32)$ \\
Air temperature & $9.8-31.6(21.05)$ & $9.8-28.3(22.07)$ \\
Water surface temperature & $8.6-27.4(18.26)$ & $4.1-26.4(19.16)$ \\
Water botton temperature & $9.4-27.4(18.15)$ & $7.9-25.8(19.25)$ \\
Secchi depth (cm) & $9-47(27.18)$ & $6-17(10.64)$ \\
PH & $7.1-8.9(8.02)$ & $7.3-8.9(8.32)$ \\
Conductivity $\left(\mathrm{iS} \mathrm{cm}^{-1}\right)$ & $188-798(468.25)$ & $246-1230(662.78)$ \\
\hline
\end{tabular}

between knots were used for the capture of specimens. The latter was used in shallow vegetated areas near the riverbanks. The fishing effort was standardized at $100 \mathrm{~m}$ of trawling.

Fishes were fixed in situ in a solution of $8 \%$ formaldehyde and then preserved in a solution of 75\% alcohol. From each specimen, standard length (SL) and body weight (W) were taken. The analysed specimens were deposited in the collection of the Museo Argentino de Ciencias Naturales "Bernardino Rivadavia" (MACN-Ict).

The species were identified according to Ringuelet et al. (1967), Aquino (1996), López et al. (2003), Monasterio de Gonzo (2003) and Reis et al. (2003).

For each locality the species richness (S) in a monthly way and the annual average were calculated; the monthly specific diversity by means of the Shannon index $(H=-\Sigma P i \ln P i)$, the derivational uniformity index $(J=H / H \max )$ (Begon et $a l ., 1995)$ and the relative abundance of each species was estimated according to the number of fishes by $100 \mathrm{~m}$ of trawling. For detect significant differences in the number of specimens between streams, a X ${ }^{2}$ test were preformed (Sokal \& Rohlf, 1981). With the obtained diversity values, a variance analysis (ANOVA) was carried out between localities, after a log-anova test on homogeneity of variances (Sokal \& Rohlf, 1981).

In each sampling place the depth and width of the river bed were monthly determined; the water and air temperature was taken, the $\mathrm{pH}$ was measured using a Lancet $\mathrm{pH}$ meter, the water conductivity was measured using a Horiba U 10 instrument and the transparence using a Secchi disc (Table 1).

The species present between $70 \%$ and $100 \%$ of the captures were considered permanent, between $30 \%$ and $70 \%$ semipermanent and less than $30 \%$ occasional (Almirón et al., 2000).

Each species was given a trophic pattern based on feeding habits of adults, taking into account invertivorous (I), piscivorous (P), omnivorous $(\mathrm{O})$, limnivorous-detritivorous (L-D) and herbivorous (H) species (Bistoni \& Hued 2002).

\section{RESULTS}

In total 8595 specimens were captured (Manantiales 3230, El Portugués 5365), pertaining to 20 species, 11 families and 5 orders (Table 2 ). The order Characiformes was the best represented, with a relative abundance of $50 \%$ and nine species, followed by the order Siluriformes with a relative abundance of $30 \%$ and six species and the order Cyprinodontiformes with a relative abundance of $10 \%$ and two species.

Characidae was the most widely represented family with a relative abundance of $35 \%$ and 7 species, followed by Callichthyidae with a relative abundance of 5\% and one species, Curimatidae with a relative abundance of $5 \%$ and one species, and the Anablepidae and Poeciliidae families with a relative abundance of $10 \%$ and one species each of them.

In the Manantiales, specimens pertaining to 20 species were captured, $(S=20)$. The highest richness value corresponded to May $(\mathrm{S}=14)$ and the lowest value to August $(S=8)$. The annual average of monthly richness indices for the Manantiales was 11.7 with a standard deviation of 1.7 .

In El Portugués 17 species were found $(S=17)$ throughout the year. The highest richness value corresponded to May and January $(\mathrm{S}=14)$ and the lowest value $(S=8)$ to July and February. The annual average of the monthly richness values for El Portugués was 11 and the standard deviation was 2.21 .

The monthly comparative analysis of species richness between the Manantiales and El Portugués (Fig. 2) shows curves with a similar trend, with a sharp fall in February and small differences during August, September, January and April. 
Table 2. Specific composition of species captured in the Manantiales and El Portugués streams. N (number of specimens), W (total weight in grams). TG: trophic group, I: invertivores, P: piscivores, O: omnivores, L-D: limnivoredetritivores, $\mathrm{H}$ : herbivores.

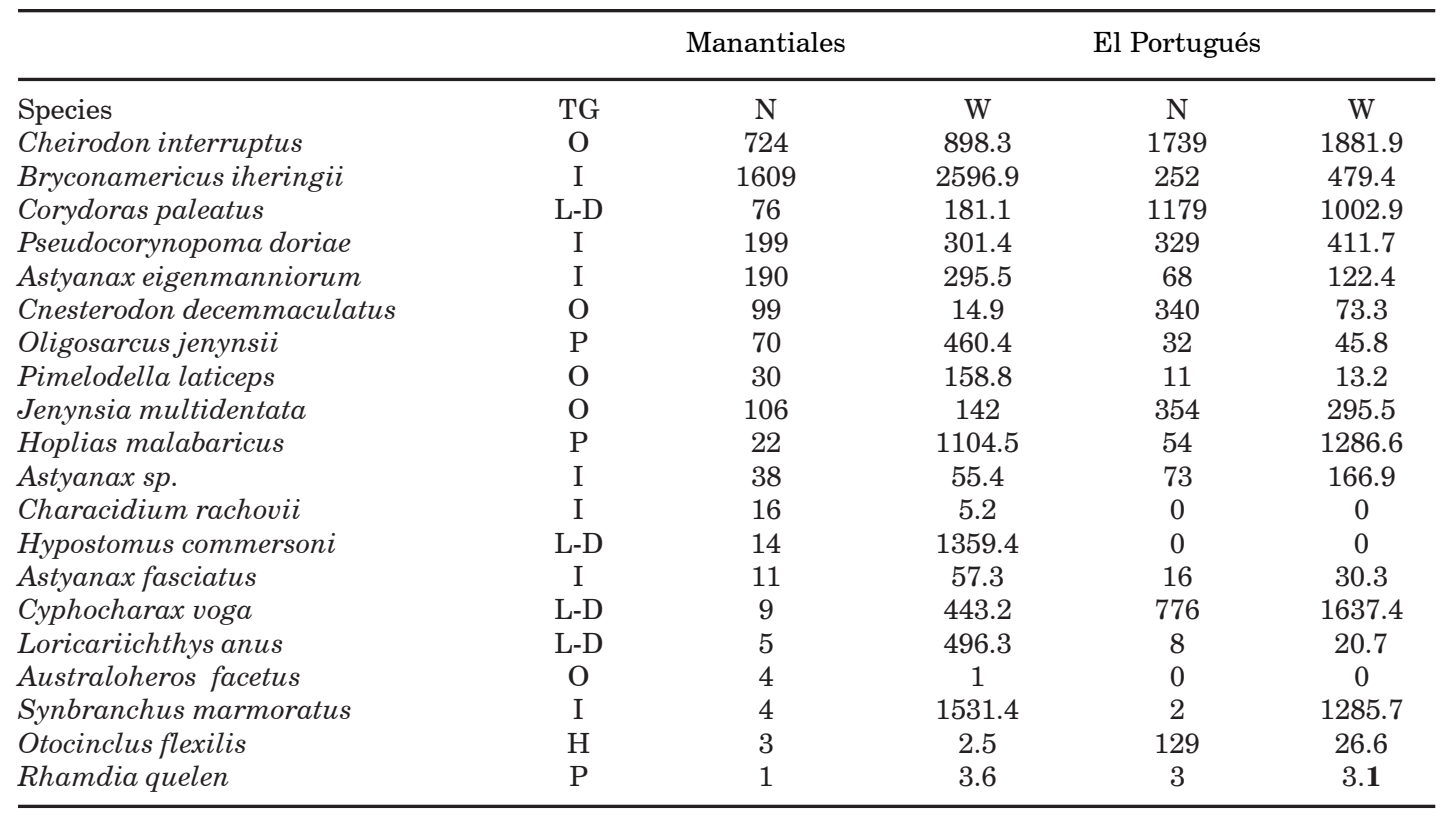

Table 3. Total $\mathrm{N}$ values, relative abundance in $\%$, and permanent, semipermanent or occasional status of the fish species in the Manantiales and El Portugués streams. Higher relative abundance in bold.

\begin{tabular}{|c|c|c|c|c|c|c|}
\hline \multirow[b]{2}{*}{ Species } & \multicolumn{3}{|c|}{ Manantiales } & \multicolumn{3}{|c|}{ El Portugués } \\
\hline & $\mathrm{N}$ & $\begin{array}{l}\text { Relative } \\
\text { abundance } \\
\text { in } \%\end{array}$ & $\begin{array}{l}\text { Status of the } \\
\text { fish species }\end{array}$ & $\mathrm{N}$ & $\begin{array}{c}\text { Relative } \\
\text { abundance } \\
\text { in } \%\end{array}$ & $\begin{array}{l}\text { Status of the } \\
\text { fish species }\end{array}$ \\
\hline Astyanax eigenmanniorum & 190 & 5.88 & permanent & 68 & 1.27 & permanent \\
\hline Astyanax fasciatus & 11 & 0.34 & semipermanent & 16 & 0.30 & occasional \\
\hline Astyanax $s p$ & 38 & 1.18 & semipermanent & 73 & 1.36 & occasional \\
\hline Bryconamericus iheringii & 1609 & 49.81 & permanent & 252 & 4.70 & permanent \\
\hline Characidium rachovii & 16 & 0.50 & semipermanent & 0 & 0.00 & \\
\hline Cheirodon interruptus & 724 & 22.41 & permanent & 1739 & 32.41 & permanent \\
\hline Cyphocharax voga & 9 & 0.28 & semipermanent & 776 & 14.46 & permanent \\
\hline Pseudocorynopoma doriae & 199 & 6.16 & permanent & 329 & 6.13 & permanent \\
\hline Oligosarcus jenynsii & 70 & 2.17 & permanent & 32 & 0.60 & permanent \\
\hline Hoplias malabaricus & 22 & 0.68 & permanent & 54 & 1.01 & semipermanent \\
\hline Cnesterodon decemmaculatus & 99 & 3.07 & permanent & 340 & 6.34 & permanent \\
\hline Jenynsia multidentata & 106 & 3.28 & permanent & 354 & 6.60 & permanent \\
\hline Pimelodella laticeps & 30 & 0.93 & semipermanent & 11 & 0.21 & semipermanent \\
\hline Rhamdia quelen & 1 & 0.03 & occasional & 3 & 0.06 & occasional \\
\hline Corydoras paleatus & 76 & 2.35 & permanent & 1179 & 21.98 & permanent \\
\hline Hypostomus commersoni & 14 & 0.43 & semipermanent & 0 & 0.00 & \\
\hline Loricariichthys anus & 5 & 0.15 & semipermanent & 8 & 0.15 & semipermanent \\
\hline Otocinclus flexilis & 3 & 0.09 & occasional & 129 & 2.40 & semipermanent \\
\hline Australoheros facetus & 4 & 0.12 & semipermanent & 0 & 0.00 & \\
\hline Synbranchus marmoratus & 4 & 0.12 & semipermanent & 2 & 0.04 & occasional \\
\hline Total & 3230 & & & 5365 & & \\
\hline
\end{tabular}


In the Manantiales 9 permanent species were obtained, Astyanax eigenmanniorum, Bryconamericus iheringii, Cheirodon interruptus, Pseudocorynopoma doriae, Oligosarcus jenynsii, Hoplias malabaricus, Cnesterodon decemmaculatus, Jenynsia multidentata and Corydoras paleatus; 9 semipermanent species, Astyanax fasciatus, Astyanax sp., Characidium rachovii, Cyphocharax voga, Pimelodella laticeps, Hypostomus commersoni, Loricariichthys anus, Australoheros facetus and Synbranchus marmoratus; and two occasional species, Otocinclus flexilis and Rhamdia quelen (Table 3).

In El Portugués 9 permanent species were identified, A. eigenmanniorum, $B$. iheringii, $C h$. interruptus, C. voga, P. doriae, O. jenynsii, C. decemmaculatus, J. multidentata and C. paleatus; 4 semipermanent species, $H$. malabaricus, $P$. laticeps, $L$. anus and $O$. flexilis; and 4 occasional species, A. fasciatus, Astyanax sp., R. quelen and S. marmoratus (Table 3).

From the total number of specimens captured in the Manantiales, the three species with the highest relative abundance were $B$. iheringii, with 49.81\%; Ch. interruptus, with $22.41 \%$ and $A$. eigenmanniorum with $5.88 \%$, representing between the three $78.11 \%$ of the total capture (Table $3)$. The species with the highest relative abundance in El Portugués were Ch. interruptus with $32.41 \%$, C. paleatus with $21.98 \%$ and C. voga with $14.46 \%$. These three species represented $68.85 \%$ of the total (Table 3).

The annual average of the diversity index for the Manantiales was $1.42(\mathrm{DE}=0.35)$. The highest monthly diversity index of the Manantiales corresponded to September $(\mathrm{H}=1.84)$, and the lowest to February $(\mathrm{H}=0.805)$.

The annual average of the diversity index for El Portugués was $1.51(\mathrm{DE}=0.29)$. The highest monthly diversity index for the El Portugués corresponded to September $(\mathrm{H}=1.92)$ and the lowest, to May $(\mathrm{H}=0.971)$.

The comparative analysis of the monthly diversity between the Manantiales and El Portugués shows a similar trend of the curves in both environments (Fig. 3), with small differences in January and April. The total number of specimens captured monthly in the Manantiales and the El Portugués streams shows significant differences $(p<0.05)$. The months of December and January exhibit the main differences during the observed periods of the study (Fig. 4). No significant differences for the diversity between localities was found ( $\mathrm{p}>0.01)$.

The variance analysis (ANOVA) carried out with the diversity indices did not show any significant differences between both localities. The annual average of the uniformity index in the Manantiales was $0.58(\mathrm{DE}=0.14)$ and in $\mathrm{El}$ Portugués was $0.65(\mathrm{DE}=0.15)$.

The trophic composition of the ichthyofauna in both environments was characterized by the presence of 7 invertivorous species, 3 piscivorous species, 5 omnivorous species, 4 limnivorousdetritivorous species and only one herbivorous species (Table 2).

\section{DISCUSSION}

The specific composition observed in the studied streams corresponds to what is expected for the Neotropical freshwater ichthyofauna (LoweMcConnell, 1987), particularly for the northern area rivers of the ecotonal transition between the subtropical and patagonian fish (Menni, 2004), where Characiformes and Siluriformes dominate.

In the Manantiales stream specimens pertaining to 20 species were captured, whereas in $\mathrm{El}$ Portugués 17 species were recorded. This numerical composition is similar to that found in the Rodríguez River (Remes Lenicov et al., 2005), a watercourse flowing into the Río de la Plata, with 12 species shared out of the 19 recorded in this environment. These values are considerably lower than those in El Pescado River (Almirón et al., 2000) where 55 species were recorded and from which 16 species penetrate from the Río de la Plata. All species present in the studied streams are also present in El Pescado River. One of the differences observed in relation to the number of species between the studied streams and El Pescado River is due to the fact that the latter is connected the whole year with the Río de la Plata, from which it receives a continous influx of species. Moreover, this stream has a course of about $36 \mathrm{~km}$, being much longer than El Portugués stream $(16 \mathrm{~km})$, and the Manantiales stream (14 $\mathrm{km})$. The larger area of El Pescado River offers a more structurally complex habitat, with more environments available for shelter, feeding and reproduction. Many authors attribute these differences in the diversity of fish communities to the structure and complexity of the habitat (Gorman \& Karr, 1978; Schlosser, 1982b; Willis et al., 2005).

The specific richness of the studied streams is not very different from that found in streams in the coastal plain in Río Grande do Sul, Brazil, where it ranges from 23 to 28 species (Tagliani, 1994); from the source of the Araras River with 9 species (São Paulo, Brazil) (Birindelli \& Garavello, 2005) and the Felizardo River (Uruguaiana, Brazil) (Azevedo et al., 2003) which has 27 species. 


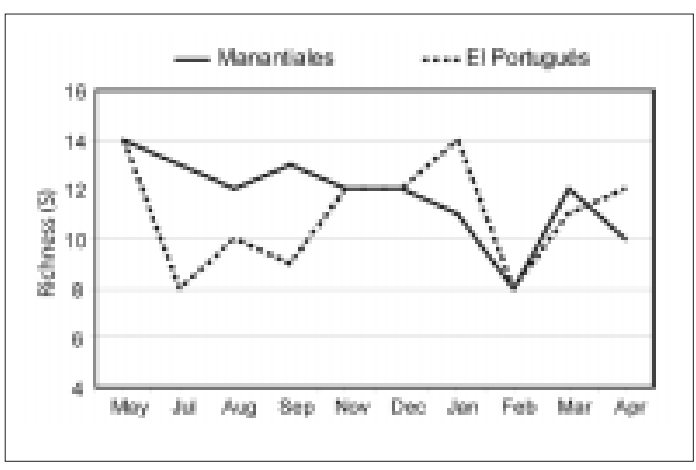

Fig. 2. Curves with the monthly values of species richness in the Manantiales and El Portugués streams.

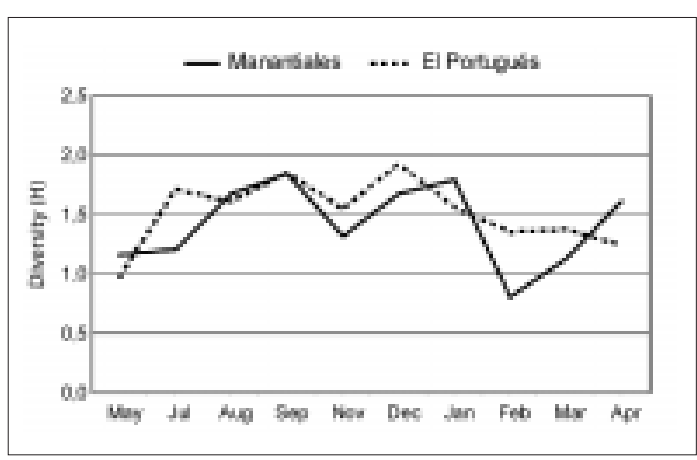

Fig. 3. Curves with monthly indices of species diversity $(\mathrm{H})$ in the Manantiales and El Portugués streams.

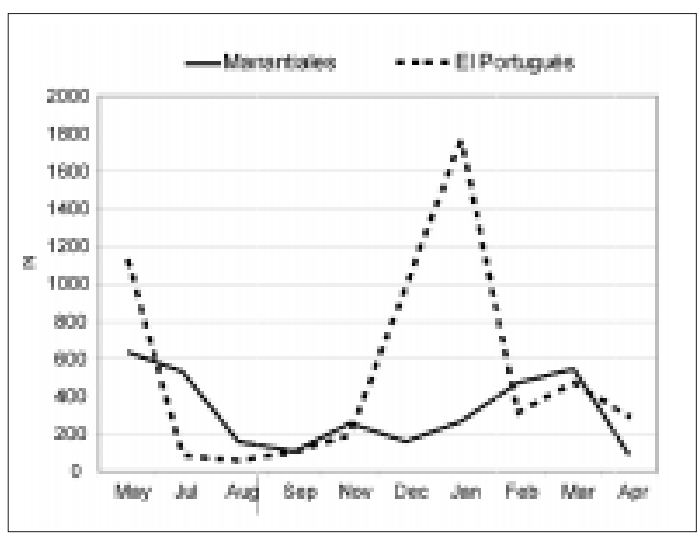

Fig. 4. Curves with total monthly $\mathrm{N}$ values in the Manantiales and El Portugués streams.

Even though the specific richness of the Manantiales stream (20) is higher than that of El Portugués (17), this latter stream has a higher specific diversity and uniformity indices than the Manantiales stream. This indicates that the fishes community individuals in the El Portugués stream would be distributed in a more regular way among the species, which is typical of a more stable community.

Diversity in these environments was lower than that observed in El Pescado River, which ranged between 1.08 and 2.04 bits (Almirón et al., 2000), but it was similar to the diversity values of low order rivers in the central area of Brazil (Melo et al., 2003) and the Corumbatai basin rivers, in São Paulo, Brazil (Cetra \& Petrere Jr., 2006).The low diversity would be due to the lotic character of the environments which, besides, are located on the southern border of the natural distribution of many species such as $P$. doriae, Ch. rachovii, O. flexilis, and, especially, H. commersoni (Almirón et al., 2000).

In the Manantiales the dominant species were $B$. iherigii, Ch. interruptus, and P. doriae, all permanent species; whereas in El Portugués stream the most captured species were $C h$. interruptus, C. paleatus, and C. voga, which are also permanent species (Table 2). These differences would be due to environmental characteristics where $C$. voga finds the best conditions for reproduction, given that in spring and summer a great number of juvenile specimens were captured. In El Portugués stream, C. paleatus finds shelter and food in vegetated areas with a lower velocity current, which are more common in this locality. Such a dominance pattern is also observed in other small-sized species, such as $O$. flexilis, J. multidentata, C. decemmaculatus and P. doriae.

In both streams richness and diversity decrease sharply in February, and the same is observed in El Portugués stream during July. In this month the lowest water temperature was recorded in this stream, coincident with an ice layer about $2 \mathrm{~mm}$ thick in almost all the open water surface. No dead fish were detected, which suggest that the fish moved to deeper environments with a higher temperature.

The rise in the captures in El Portugués stream during May and January is due to the increase of juveniles of species that spawn at the end of spring and summer. The same occurs in El Pescado River with the growth in number of larvae and juveniles that found shelter in the submerged vegetation (Almirón et al., 2000).

The ichthyofauna of both environments includes invertivorous (35\%), omnivorous (25\%), limnivorous-detritivorous $(20 \%)$, piscivorous $(15 \%)$ and herbivorous (5\%) species. Three species, which become strictly ichthyophagous when they are adults, were recorded: $H$. malabaricus, $O$. jenynsii and $R$. quelen, although only juvenile individuals were captured from the last of these three species. 
The dominance of invertivorous and piscivorous species coincides with the fact observed in rivers in the central part of the country (Bistoni \& Hued, 2002). Even though the abundance of invertivorous and piscivorous species has been considered as a good indicator of environment quality (Schlosser, 1982a; Reash \& Berra, 1987; Rodríguez-Olarte \& Taphorn, 1995) in the rivers of Córdoba Province the trophic groups do not play this role because of the low trophic diversity (Hued $\&$ Bistoni 2005). Nevertheless, the presence of $P$. doriae and Ch. rachovii (both of them are invertivorous species) in the studied streams, being indicators of a good environmental quality (Remes Lenicov et al., 2005), confirms the low anthropic impact on both environments, considering the organization of trophic levels (Meffe \& Berra, 1988; Winemiller \& Taphorn, 1989), food availability and vegetated shelters.

No exotic fauna, such as Cyprinus carpio, was observed in neither of the streams, although it is found in nearby watercourses, such as the San Vicente River, heavily impacted by the closeness to the city which bears the same name.

The dominance of individuals smaller than $100 \mathrm{~mm}$ length coincides with that observed by Castro (1999) in small South American rivers, suggesting that these environments comprise reproduction and breeding areas. This explains the increase in bigger-sized species biomass, such as $H$. malabaricus, R. quelen, C. voga and S. marmoratus during the spring and summer months; that in addition to finding appropriate environments for their reproduction have a variety of food available. During the whole year in the two studied streams, the most abundant species are permanent, as in El Pescado River, where Almirón et al. (2000) found that this "persistence" is due to the continuous water availability and mild temperatures.

\section{ACKNOWLEDGEMENTS}

To Roberto C. Menni for his critical reading of the manuscript and our colleagues of the División Ictiología for their help.

\section{BIBLIOGRAPHY}

Almirón, A.E., S.E. Gómez \& N.I. Toresani. 1992. Peces de agua dulce de la provincia de Buenos Aires. 1-29 p. En: H.L. López \& E.P. Toni (eds.). Situación ambiental de la provincia de Buenos Aires 2(12). Buenos Aires, Argentina.

Almirón, A.E., M.L. García, R.C. Menni, L.C. Protogino \& L.C. Solari. 2000. Fish ecology of a seasonal lowland stream in temperate South America. Mar. Freshwater Res. 51:265-274.
Aquino, A.E. 1996. Redescripción de Otocinclus flexilis Cope, 1894 (Siluriformes, Loricariidae, Hipoptopomatinae) con un nuevo sinónimo. Iheringia, Ser. Zool. 81:13-22.

Azevedo, C., E. Pessano, D. Tomassoni, M.V. Querol \& E. Querol. 2003. Diversidade específica, densidade e biomassa da ictiofauna da nascente do arroio Felizardo, Bacia do Rio Uruguay Médio, Uruguaiana, RS, Brasil. Biodiversidade Pampeana 1(1):35-45.

Begon, M., J.L. Harper \& C.R. Townsend. 1995. Ecología. Individuos, poblaciones y comunidades. Ediciones Omega. Barcelona.

Birindelli, J.L.O. \& J.C. Garavello. 2005. Composiçào e sazonalidade da ictiofauna do ribeirao das Araras, Bacia do Alto Rio Paraná, Sào Paulo, Brasil. Comun. Mus. Ciénc. Tecnol., Sér. Zool. 18(1):37-51.

Bistoni, M.A. \& A.C. Hued. 2002. Patterns of fish species richness in rivers of the central region of Argentina. Bras. J. Biol. 62(4B):353-364.

Castro, R.M.C. 1999. Evoluçâo da ictiofauna de ríachos sulamericanos: padrôes gerais e possíveis processos causais. En: E.P.R. Caramaschi, R. Mazzoni \& P.R. Peres-Neto (eds.). Ecología de peixes de riachos. Série Oecologia Brasiliensis. 139-155pp.

Cetra, M. \& M. Petrere Jr. 2006. Fish-assemblage structure of the Corumbatai river basin, Sâo Paulo State, brazil: characterization and anthropogenic disturbances. Braz. J. Biol. 66(2A):431-439.

Gorman, O.T. 1988. The dynamics of habitat use in a guild of Ozark Minnows. Ecological Monographs 58(1):1-18.

Gorman, O.T. \& J.R. Karr. 1978. Habitat structure and stream fish communities. Ecology 59(3): 507-515.

Hued, A.C. \& M.A. Bistoni. 2005. Development and validation of a Biotic Index for evaluation of environmental quality in the central region of Argentina. Hydrobiologia 543:279-298.

Liotta, J. 2006. Distribución geográfica de los peces de aguas continentales de la república Argentina. ProBiota, Serie Documentos $\mathrm{N}^{\circ}$ 3:701 pp.

López, H.L. 1990. Apuntes ictiológicos del río Reconquista (Pcia. De Buenos Aires). Bol. Asoc. Arg. Limnol. 5:15-16.

López, H.L., C. Baigún, J. Iwaszkiw, R. Delfino \& O. Padin. 2001. La cuenca del Salado: uso y posibilidades de sus recursos pesqueros. Editorial de la Universidad de La Plata, La Plata. 76 pp.

López, H.L., C.C. Morgan \& M. Montenegro. 2002. Ichthyological ecoregions of Argentina. Documents Series, ProBiota, on line version.

López, H.L., A.M. Miquelarena \& R.C. Menni. 2003. Lista comentada de los peces continentales de la Argentina. ProBiota, Serie Didáctica $N^{\circ}$ 5: 1-85.

Lowe-McConnell, R.H. 1987. Ecological studies in tropical fish communities. Cambridge Univ. Press, Cambridge. 382 pp.

Matthews, W.J. 1998. Patterns in Freshwater Fish Ecology. Chapman and Hall. 752 pp.

Meffe, G.K \& T.M. Berra. 1988. Temporal characteristics of fish assemblage structure in a Ohio streams. Copeia 3:684-690.

Melo, C.E., F.A.Machado \& V.P. da Silva. 2003. Diversidade de peixes em um córrego de cerrado no Brasil Central. Braz. J. Ecology 2003(1-2):17-23. 
Menni, R.C. 2004. Peces y ambientes en la Argentina continental. Monogr. Mus. Argentino Cienc. Nat., 5:1316.

Monasterio de Gonzo, G. 2003. Peces de los Ríos Bermejo, Juramento y Cuencas Endorreicas de la Provincia de Salta. Museo de Ciencias Naturales y Consejo de Investigación, Universidad Nacional de Salta. 243pp.

Querol, E.; M.V.M. Querol \& J.L. Cervia. 1997. Estimativa da densidade e biomassa da populaçao do Cichlasoma portalegrensis (Hensel, 1870) (Pises, Cichlidae) a través do método do três Capturas sucesivas com Pesca Eléctrica em um Arroio do Pampa. Com. Mus. Ciénc., Sér. Zoología 10:13-25.

Reash, R.J. \& T.M. Berra. 1987. Comparison of fish communities in a clean-water stream and a adjacent polluted stream. Am. Midl. Nat. 118(2):301-322.

Reis, R.E.; S.O. Kullander \& C.J. Ferraris, Jr. 2003. Chek list of the freshwater fishes of South and Central America. Edipucrs. Porto Alegre, Brazil.

Remes Lenicov, M.; D.C. Colautti \& H.L. López. 2005. Ictiofauna de un ambiente lótico suburbano: el arroyo Rodríguez (Buenos Aires, Argentina). Biología Acuática 22:223-230.

Ringuelet, R.A. 1961. Rasgos fundamentales de la zoogeografía de la Argentina. Physis 22(63):151-170. - 1975. Zoogeografía y ecología de los peces de aguas continentales de la Argentina y consideraciones sobre las áreas ictiológicas de América del Sur. Ecosur 2(3):1-122.
Ringuelet, R.A., R.H. Aramburu \& A.A. de Aramburu. 1967. Los peces argentinos de agua dulce. Comisión Científica de la Provincia de Buenos Aires. La Plata, Argentina. 602 pp.

Rodríguez-Olarte, D. \& D.C. Taphorn. 1995. Los peces como indicadores biológicos: aplicación del índice de integridad biótica en ambientes acuáticos de los llanos occidentales de Venezuela. Biollania 11:27-56.

Schlosser, I.J. 1982a. Trophic structure, reproductive success, and growth rate of fishes in a natural and modified headwater stream. Can. J. Fish. Aquat. Sci. 39:968-978

- 1982b. Fish community structure and functions along two habitat gradient in a headwater stream. Ecological Monographs 52(4):395-414.

Sokal, R.R. \& F.J. Rohlf. 1981. Biometry. W.H. Freeman, New York. 859p.

Tagliani, P.R.A. 1994. Ecologia da assembléia de peixes de trés riachos da planicie costeira do Río Grande do Sul. Atlántica 16:55-68.

Willis, S.C.; K.O. Winemiller \& H. Lopez-Fernandez. 2005. Habitat structural complexity and morphological diversity of fishes assemblages in a Neotropical floodplain river. Oecologia 142:284-295.

Winemiller, K.O. \& D.C. Taphorn. 1989. La evolución de las estrategias de vida en los peces de los llanos occidentales de Venezuela. Biollania (6):77-123.

Wootton, R.J. 1990. Ecology of teleost fishes. Chapman and Hall, New York. 404 pp. 